\title{
Globalization and the erosion of geo-ethnic checkpoints: evolving signal-boundary systems at the edge of chaos
}

\section{Chris Girard ${ }^{1}[0$}

Published online: 21 November 2019

(c) The Author(s) 2019

\begin{abstract}
Spatial boundaries, thermodynamic-economic specialization, and signal processing are at the core of evolution's major transitions. Centered on these three dimensions, a proposed evolutionary informatics model roots ethnic and racial cleavages in zero-sum contests over rivalrous resources within geophysical sites. As the geophysical boundaries and signal-processing complexity of social systems coevolved, zero-sum contests centered on metropoles extracting resources from hinterlands. In this colonial extraction process, racialization arose from non-market spatial segregation of populations tagged with hinterland lineage. Subsequent post-industrial erosion-and greater permeability — of racial and ethnic boundaries has been enabled by the progressive uncoupling of more highly evolved complex adaptive systems from geophysical location (non-territorial adaptation). Signal and physical topologies are becoming more distinct. This uncoupling from physical location is driven by cybernetic parallelism in complex adaptive systems: diverse and independent agents learning from their mutual exchange of signals. Cybernetic parallelism has generated epistemic and geopolitical challenges to formal apartheid and racializing immigration policies, but not without friction or reversals.
\end{abstract}

Keywords International economic history · Complex adaptive systems · Racialization $\cdot$ Signal-boundary systems $\cdot$ Evolutionary informatics $\cdot$ Ecology

JEL Classification F60 $\cdot$ J15 $\cdot$ N50 $\cdot \mathrm{O} 30 \cdot \mathrm{Q} 57 \cdot \mathrm{R} 11 \cdot \mathrm{R} 12$

Chris Girard

girardc@fiu.edu

1 Department of Global and Sociocultural Studies, Florida International University, 11200 SW 8th Street, Miami, FL 33199, USA 


\section{Introduction}

The digital age is abandoning conceptions of "ethnicity" and "race" that are essentialist, static, or context-free. Embracing digital-era insights on data flows and connectivity, this research adopts an informatics perspective. ${ }^{1}$ The proposed paradigm is buttressed by adding evolutionary and complexity theories to examine changes in information processing. With this digital-era focus, racial and ethnic signals ${ }^{2}$ can be seen as coevolving with society's geospatial dynamics. It is theorized that the major impetus is evolving signal-processing complexity that realigns global geospatial barriers. Signal processing governs whether groups with distinct ancestral geographic origins-tagged with racial-ethnic signifiers-pass through geospatial checkpoints in workspaces, neighborhoods, countries, and other bounded social domains.

Focusing on evolving complexity in signal-boundary systems, two interrelated propositions are formulated. The first proposition applies if rivalrous ${ }^{3}$ resources are inseparable from a specific geophysical location (hereafter referred to as "fixed-site rivalrous resources"). In zero-sum contests for control of this specific location and its resources, an ethnic group consistently denied full spatial access or control is subject to racialization. That is, the group can be tagged as inherently inferior. Second, in the post-industrial era, the coevolution of signal-processing complexity and nonterritorial $^{4}$ adaptation will overall diminish racialized cleavages. Both these propositions suggest that ethnic-racial boundaries do not emerge from inherent qualities of signified entities-i.e., ethnic groups or so-called "races." Unlike physical or material objects viewed as discrete entities, signals convey information about system ${ }^{5}$ dynamics and only derive meaning from the systems that process them (Holland 2012).

\section{Boundary changes and the thermoeconomic aspects of an evolutionary informatics model}

Increasing signal-processing complexity, as a key factor impacting racial-ethnic boundaries, may be rooted processes also found in biological evolution. For example, in one of evolution's most significant transitions, the rigid outer cell wall in prokaryotes was replaced by a permeable membrane. The softer boundary paved the

\footnotetext{
1 Informatics studies the "representation, processing, and communication" of information in natural and artificial systems such as biological molecules, electronic devices, nervous systems, computers, societies, "large-scale distributed systems," etc. (University of Edinburgh 2016).

2 A "signal" is defined here as an action conveying information or instructions.

3 This means that additional resource users will reduce benefits, injecting a zero-sum dynamic.

4 Among many meanings, "territorial" here refers to site-specific dominance that assures priority access to resources - thereby reducing competition and uncertainty (see Meagher 2014).

5 Weidlich (2000: 7) defines a "system" as a "stratum of reality with a certain self-contained structural organization" that "possesses properties that cannot be attributed to the parts." In contrast, "race" is an essentialist-physicalist concept, reifying the attributes of discrete parts.
} 
way for eukaryotes-more complex life forms with cellular nuclei. ${ }^{6}$ Eukaryotes may have absorbed mitochondria through the permeable cell walls. This initiated thermoeconomic specialization, whereby increased energy from the ingested mitochondria permitted more information-carrying genes in the nucleus. Signal-processing complexity, ${ }^{7}$ then, coevolved with energy-boosting specialization: a thermoeconomic division of labor between the mitochondria, nucleus, and the rest of the cell (cf. Adam Smith's The Wealth of Nations; see Corning and Kline 1998). In turn, a further division of labor between protein-synthesizing RNA and nucleus-based DNA gave signal processing inside the cell's nucleus greater independence from the surrounding physical environment (Jablonka and Lamb 2006; Szathmáry 2015). In part, more genetic complexity was enabled when chromosomes were no longer necessarily attached to the cell wall. Initiated by the eukaryote's permeable cell walls, then, signal processing became less anchored to a specific physical location. Indeed, this may embody the basis for all major transitions in biological evolution-namely, more inclusive boundary realignments that coevolve with "novel ways of storing, transmitting and using information" (see Corning and Szathmáry 2015: 48; Maynard Smith and Szathmáry 1995, 1999; Szathmáry 2015). Using this evolutionary informatics model, new ways of processing signals will be shown to erode racial-ethnic barriers, much like eliminating the rigid wall in prokaryotes.

Successful ecological adaptation of systems, which includes adaptation of racial-ethnic barriers, is constrained by probabilistic processes and by path dependency (cf. Darwin's (1859) principles of descent and divergence). Adaptive responses may fail to address pollution and irreparable environmental damage resulting from energy throughputs-fuel, fiber, and food (von Schilling and Straussfogel 2009). Ensuing environmental chaos or "entropy debt" can tax complex systems and cause them to collapse (see Arthur 1994; Dyke 1988; Foster 2011: 18; Tainter 1988). For example, such a threat is posed by global warming. In addition, racial-ethnic barriers can incur system-taxing entropic debt. As will be shown below, this may have been a factor in the collapse of colonial empires.

\section{Racial barriers and "tools of empire": policing spatial enclosures for resource extraction}

The first proposition-formulated in the introduction-roots racial-ethnic signals within socio-ecological systems with geophysical boundaries. For most of human history, these systems were centered on extracting biotic and mineral resources

\footnotetext{
${ }^{6}$ Natural selection may favor complexity only in certain co-evolutionary contexts (Mayfield 2013). For example, prokaryotes outnumber more complex eukaryotes (Szathmáry 2015).

7 Complex living systems both "interact with and internally represent other entities of their environment" (Kauffman 1993: 232). Accordingly, complexity could be potentially measured by "the amount of information that the ensemble [an average of coded sequences] has about the environment to which it adapts" (Adami 2002: 1078). Another measure could be computational compression depth developed by Lathrop (1997). This is not yet calculable for physical entities (Mayfield 2013), but algorithmic fab-lab and bioengineering technologies may make inroads.
} 
(see Haberl et al. 2011; Stein 1999). Moreover, over the last five centuries, this extraction led to "unequal ecological exchange" undergirding the spatially expansive signal-boundary systems of Europe and eventually Japan (see Moore 2000). According to Ross (2017), the process was unequal, because expansive empires depleted resources in hinterlands generically referred to as "tropical landscapes." Given the specific dynamics of hierarchically organized empires, these landscapes and the indigenous inhabitants were sacrificed to grant colonizers a vital resource subsidy. That is, tropical landscapes suffered wanton environmental destruction through deforestation, soil erosion, diminished local biodiversity, and disrupted food chains. Extensive damage was done to rivers, hills, valley floors, and aquatic ecosystems (see World Bank 2003). Such damage could be conceptualized as entropy debt.

Integral to unequal ecological exchange, empire-directing metropoles have basked ideologically in their perceived "victory" over nature and matter (see Adas 1989). This presumed victory included dominance over purportedly primitive, inefficient, and irrational peoples tagged by tropical geographic origins (Ross 2017). Although recent brain-scanning research confirms that power holders in general view others instrumentally (Fisk 2011), colonial dominance motifs would appear to resonate the insuperable power bestowed by "tools of empire" (Headrick 1981; Ross 2017). These resource-depleting tools-particularly fossil-fuel-driven and electricity-powered machines-provided colonizers with overpowering bursts of energy and superior armaments. Enduring power over tropical hinterlands signaled to the colonizers that they constituted the hub of a sociospatial array. Racialization arose from the hub's downward-radiating spokes universally ensnaring tropical and other hinterland peoples.

The physicalist hub-and-spokes view of dominance over tropical landscapes and peoples obscured "complex webs of interconnection" between crops, soil, disease, and climate (see Azzi 1956; Ross 2017). Whereas pre-colonial tropical peoples relied on regeneration through photosynthesis-drawing energy from human and animal muscles and from burning wood-colonial metropoles employed "tools of empire." These tools extracted resources from hinterlands at a rate faster than these resources could be replenished (Tucker 2000). Consequently, although the hierarchical signal-boundary system provided the colonizers with concentrated firepower at strategic moments in history, the hierarchy could not be sustained indefinitely. There are limits to expending resources without renewing them. For example, the ecological mismatch of the metropole's largescale agricultural projects was epitomized by the failure of a British groundnut project in Kongwa, Tanzania in 1951 (Rizzo 2006) and the collapse a French oil palm project in Dahomey one decade later (Havinden and Meredith 1993; Dumont 1966; Ross 2017). Although the colonial metropolitan elite confidently expressed racializing contempt for tropical farmers, over time there was nonetheless a growing chorus of respect for ecologically adaptive indigenous practices: crop interleaving and rotation, shallow plowing, controlled natural ground cover, and regenerative forestry-management methods (see Azzi 1956; Faulkner and Mackie 1933; Jones 1936; Ross 2017). 


\subsection{Geo-ethnic checkpoints and global non-market channeling via spatial enclosure}

Evolutionary informatics links racial-ethnic boundary construction ${ }^{8}$ with zero-sum contests over fixed-site rivalrous benefits. Such contestation was integral to colonialism's unequal ecological exchange. Seeking maximal flow of resources into the colonial metropole's treasury at the expense of hinterlands, mercantilist empires exported processed goods such as textiles and imported unprocessed inputs such as cotton (Findlay and O'Rourke 2007; Pincus 2012). Notably, this unequal exchange did not derive from a free market, but from policed channeling: enclosing and policing non-domestic space-often in ethnically distinct hinterlands - to guarantee a sufficient quantity of relatively unprocessed inputs. For example, eighteenth-century and nineteenth-century British textile manufacture - the springboard for the wider industrial revolution - relied on cotton cultivated by slave labor on land from which the indigenous people had been forcibly removed (Beckert 2015). Spatial checkpoints, based on police power, barred free movement or exchange for tropical and other hinterland peoples.

Interdisciplinary findings suggest that policed channeling of resources and people can prevail over voluntary exchange if the rivalrous benefits for a group are inseparable from a specific geophysical location. Such fixed-site benefits would include an ethnic group's control over prime real estate, office space, farmland, or an area's politics and culture. These fixed-site benefits may lose value if exchanged or shared with outside groups tagged with lineage from another territory. Unlike the dynamics for an expanding supply of manufactured goods, more consumers in more places do not increase benefits from economies of scale. For example, fixed-site rivalrous benefits motivate resident populations to exercise non-negotiable control over identitybestowing homelands (Berg 2007; Toft 2002) and to exclude others from resourcepoor areas lacking divisible assets (Carpenter and MacMillen 1976; Cashdan 1983; Toft 2002). ${ }^{9}$ To reiterate, this is because a distributional zero-sum limit is eventually reached for non-expandable fixed-site resources, whether these are identity-bestowing, mineral, or biotic (see bottom panel in Fig. 1). These zero-sum group dynamics can also be triggered by fixed-site factor endowments. This can be seen for sugar, cotton, and indigo harvests limited to tropical landscapes, where free cultivators

\footnotetext{
8 Evolutionary informatics would view "races" as socio-spatial constructs (synthetic view) rather than as discrete genealogical entities (physicalist view). Indeed, Lewontin (1972) shows non-concordance among human traits within "racial" categories. A critique of these findings by Edwards (2003) at best shows multiple-loci allele frequencies can accurately pinpoint ancestral geographic origins in Africa, Asia, Europe, etc. Identifying the spatial origins of genetic tags does not in itself explain racialized geo-ethnic hierarchies (see Marks 2010; Roberts 2011).

9 Toft (2002: 87-90) observes that a homeland "is not an object that can be exchanged, but an indivisible attribute of group identity [because]... losing control of homeland territory may result in dilution of the national group, its loss of power...." Berg (2007: 205) observes that "a zero-sum game" emerges from exclusionary groups patrolling the earth's homelands. It should be noted that territory-based lineage groups, demarcated by ethnic tags, can shift their territorial boundaries over time.
} 
would be too costly (see Engerman and Sokoloff 1997; Fredrickson 1981). ${ }^{10}$ In response, European empires used police power to spatially wall-in tropical resources and peoples. For example, slaves produced cotton on land from which indigenous inhabitants were forcibly cleared (see Beckert 2015).

Colonial empires spatially walled-in hinterland resources and peoples using geo-ethnic checkpoints. That is, based on a group's lineage and geographic origins, these checkpoints restricted freedom of movement and market access (negotiation as free agents). Although such discriminatory practices can reduce market efficiency (Becker 1971), market exchange among free agents may depend on evolutionary complexity. For signal-boundary systems in the territory-expanding stage of evolution, fixed-site resources (biotic, mineral, identity-bestowing, etc.) that are rivalrous can engender a zero-sum dynamic. Consequently, competitors with greater "resource holding potential" (ability to win an all-out contest) use their superior power to wall-in these resources for either exclusive or priority use (see Johnson and Toft 2013: 22).

\subsection{Duress from domestic geo-ethnic checkpoints channeling fixed-site rivalrous benefits}

Even in the contemporary United States, spatial checkpoints continue to channel fixed-site benefits away from peoples with hinterland lineage. Although black spatial isolation from whites has been contracting by about $5 \%$ per decade since 1970, as recently as 2010 blacks were still hypersegregated in 21 metropolitan areas (Massey and Tannen 2015; Massey and Wagner 2018: 147). ${ }^{11}$ Notably, this hypersegregation represents a form of spatial confinement having non-market origins. In 1917 the Chicago Real Estate Board-and somewhat later, the National Association of Real Estate Boards-officially adopted a policy that led to expelling any of their agents who brokered black purchases or leases in white neighborhoods (Jones-Correa 2000-2001; Philpott 1991; Roithmayr 2014). Because of the dual housing market created by restrictive covenants and sustained by racial steering by realtors, white neighborhoods have provided higher home appreciation rates than have black neighborhoods (Massey and Denton 1993; Oliver and Shapiro 2006). Although racial covenants are no longer legal, rivalrous benefits from racial steering and racially aligned school districts may be locked in by path-dependent switching costs. According to

\footnotetext{
${ }^{10}$ Engerman and Sokoloff (1997) analyze factor endowments that include climates and soil conditions favoring large plantations-cultivating sugar, cotton, coffee, tobacco, and rice-for which economies of scale favor servitude. Fredrickson (1981: 55) notes that the requisite "gang-type labor almost invariably creates pressure for some kind of involuntary system." Wages for this backbreaking work are driven unprofitably high "where labor is relatively scarce and land is plentiful" because free agents—with land access_-opt for being independent farmers or foragers.

11 Hypersegregation is defined by a score of 60 or more on four out of five dimensions of segregation: clustering, concentration, centralization, evenness, and isolation (Massey 2004; Massey and Denton 1988). In larger cities where most blacks reside, segregation levels are static (Massey and Wagner 2018).
} 


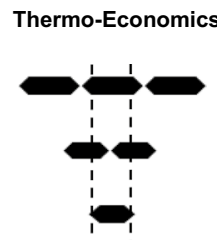

Relatively Location-free Non-rivalrous Resources

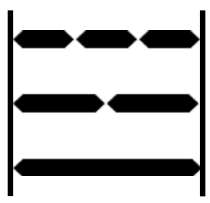

Fixed-Site Rivalrous Resources

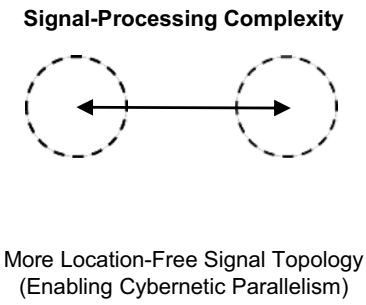

(Enabling Cybernetic Parallelism)

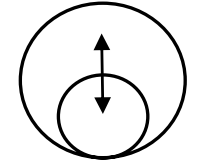

Signal Topology $=$ Physical Topology (Enabling Cybernetic Hierarchy)
Horizontal

Boundary

Alignment

Decolonization

Global Alliances

Global Epistemic

Communities

Formal Apartheid

Dismantled

All 22 Countries in

Americas sign

ICERD

\section{Hierarchical}

Boundary

Alignment

Colonial

Enclosure of

Ethnic Hinterlands

Racially

Restrictive

Covenants

Mass

Incarceration of

Inner-City Blacks

Nativist Backlash

outside Globally

Connected Nodes

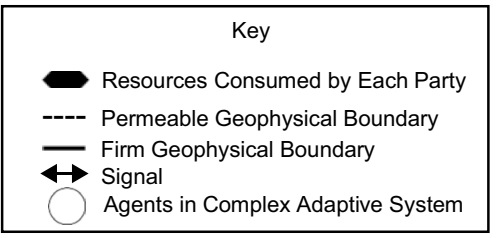

Fig. 1 Coevolution toward location-free signal topology and non-rivalrous resources

Roithmayr (2014), this would hold for politically costly legal remedies seeking to eliminate dual ("racially" partitioned) housing markets. ${ }^{12}$

Racial-ethnic channeling of fixed-site resources engenders entropy debt. Exacerbating maintenance costs for geo-ethnic boundaries, there has been an escalation of police surveillance and street patrols in black neighborhoods that began in the mid1960s (Hinton 2016). In the wake of violent civil disturbances erupting in U.S. inner cities from 1965 to 1968, municipal police patrolling black neighborhoods received

\footnotetext{
${ }^{12}$ For example, inclusionary zoning could result in white-neighborhood property depreciation (Arthur 1994) and reduce school financing, generating "homevoter" hostility (Roithmayr 2014).
} 
"military-grade rifles, tanks, riot gear, walkie-talkies, helicopters, and bulletproof vests" (Hinton 2016: 89). Subsequently, the criminal justice system's supervision of black residents has become especially prominent in hypersegregated cities such as Chicago (Alexander 2012). For example, more than half of black adult males in the Chicago's Cook and collar counties had felony convictions in the year 2000 (Street 2002: 17). Between 1968 and 2004, the total proportion of US adult black males convicted of a felony rose dramatically from 15 to 33\% (Uggen et al. 2006: Table 2). This trend has greatly increased policed spatial confinement of young black males in prisons and jails, a costly form of human warehousing adding to inner-city entropy debt (see Alexander 2012; Western 2006). "Racial" signal and physical topologies overlap, the signals being conveyed via direct police contact (see Fig. 1). Unlike most citizens, inner-city blacks are daily confronted with police surveillance and frequently submit to preemptive personal searches (Hinton 2016).

By allocating fixed-site rivalrous benefits, spatial (particularly residential) segregation is crucial for sustaining other racial-ethnic boundaries (see Massey and Denton 1993). Cordoning off space_-and by default the resources within it-achieves both efficiency and the appearance of bias-free neutrality. That is, when the spatial partitioning of people governs resource allocations, it is not necessary to designate the specific groups or specific resources for which access is either explicitly permitted or denied (Sack 1983). Instead, spatial partitioning permits disparate-impact resource allocation to be politically neutralized through naturalization: differences between areas are simply rationalized as "that's the way it is" (Bonilla-Silva 2018: 64-67). For example, black residential segregation concentrates poverty, inducing entropic biosocial costs such as shortened telomeres and heightened allostatic loads (Massey and Wagner 2018). ${ }^{13}$ These costs are most visibly associated with characteristics of black inner-city areas-e.g., violent crime-rather than socio-spatial resource allocation. The view that these black health costs are entirely self-inflicted achieves credibility only through segregation that appears to be de facto or spatial rather than explicitly created in laws and in practices. This same logic can even be applied to property distribution under legal slavery, insofar as efficient resource allocation required passes and nonstop patrolling to block slave access to most white spaces (Camp 2004). Ultimately, then, ethnic and "racial" economies thrive when spatial (especially residential) segregation creates separate social networks (see Fig. 1). In turn, these separate networks restrict the inflow of social, cultural, and human capital that enables employment, exogamous marriage, and other social opportunities for people with hinterland lineage (Montgomery 1991; Roithmayr 2014; Tassier and Menczer 2008).

\footnotetext{
13 Mitchell et al. (2014) report nine-year-old black boys in more disadvantaged environments had shorter telomeres, a biomarker indicating chronic stress. Schulz et al. (2012) found that allostatic load-an adrenaline-releasing threat response-is associated with neighborhood poverty.
} 


\section{Innovation on the edge of chaos: requisite variety and recirculation's multiplier effects}

The first proposition has linked geo-ethnic checkpoints to agro-industrial society's reliance on fixed-site resources. The second proposition predicts that system barriers rooted in geophysical location - including racial-ethnic barriers-can potentially be penetrated, eroded, or realigned by a society's signal-processing complexity. Borrowing from biological evolution and computer science experiments, it appears that a more inclusive realignment of a system's geospatial boundaries coevolves with the system's signal-processing complexity. Specifically, computer science experiments suggest that nonlocal adaptation - the ability to handle new situations-is accelerated by spatially independent co-evolutionary competitors feeding on each other's improvements (Mayfield 2013). Such competitor evolution illustrates that more inclusive geospatial boundary alignments in complex adaptive systems permit diverse and independent agents to learn from their mutual exchange of signals (see Holland 2006). Indeed, this signal-processing feature, labeled here as cybernetic parallelism, renders human brains remarkably creative (see Mayfield 2013). ${ }^{14}$ Cybernetic parallelism - illustrated by the free exchange of ideas among diverse and independent thinkers-advances scientific discovery. More diversity enhances adaptive success according to Darwin (1859). Moreover, repeated computer experiments show that the special circumstances generating co-evolutionary pressure can cause competitive advantage to shift. The shift is from a system's rigid protective structure to increasingly rapid and deep signal processing - that is, faster-acting algorithms that become more intricately layered and less compressible (see Lathrop 1997; Kim and Ashlock 2017). ${ }^{15}$ Accordingly, a derivative corollary is that a society's increasing signal-processing complexity makes adaptive capacity depend less on the system's geophysical boundaries (measured by size and strength) and more on signalprocessing depth or speed (see top of Fig. 1). Finally, major complexity-enhancing boundary realignments of this nature are most likely at the edge of chaos (see Kauffman 1993; Wolfram 2002). ${ }^{16}$ The intersection of flux-free and high-flux environments appears to spawn complexity.

Cybernetic parallelism ostensibly bestows adaptive advantage. The advantage comes through ever more inclusive, boundary-expanding feedback loops recirculating energy (resources) and information through a division of labor

\footnotetext{
14 According to Mayfield (2013: 248), "the massive parallelism of the cerebral cortex" permits multiple alternative propositions or models "to be simultaneously worked on by multiple parallel attempts." This reciprocity between cerebral centers appears to expand innovative potential.

15 Lathrop (1997) employed a genetic algorithm to select agents according to their scores in a game called "iterated prisoner's dilemma." The evolving agents continually improved strategies over many generations. Gaged by a Lempel-Ziv algorithm, the compression depth (declining compressibility) of agent programs increased over 3500 generations. Also, researchers using different games and control conditions found greater nonlocal adaptation for later generations in co-evolutionary environments (Kim and Ashlock 2017). By inference, then, rigid protective structures would reduce nonlocal adaptation in high-flux co-evolutionary environments.

${ }^{16}$ For example, evolution of the walls fully enclosing protocells required free-flowing liquids to strike a chaos-mediating surface (Maynard Smith and Szathmáry 1995, 1999).
} 
(thermoeconomics). One example is the development of positive feedback loops that enhance resource usage among cooperative, cross-feeding microbes (Carlson et al. 2018; Pacheco et al. 2019). These non-rival benefits result when iterative cooperative exchanges enhance resource accumulation (Chadefaux and Helbing 2010). ${ }^{17}$ The germane axiom for signal-boundary systems, then, is this: increasing system complexity can enhance system sustainability (adaptation) by recirculating or exchanging resources in innovation-testing feedback loops (Benbya and McKelvey 2006; Holland 2012; Kauffman 1993). ${ }^{18}$ Feedback loops increase the system's adaptive or competitive advantage by (1) conserving resources through constantly recirculating them in a more complex system incorporating realigned boundaries (an adaptation to increasing entropy or the second law of thermodynamics); (2) obtaining resource multiplier effects through a more synergetic division of labor with realigned boundaries; and (3) increasing the system's requisite variety, so that it has sufficient internal diversification for managing varied external disturbances (see Holland 2012; see Ashby 1956 for the law of requisite variety). The geospatial realignments in an evolutionary informatics sequence suggest the following: insofar as racial-ethnic cleavages are endemic to less complex, space-enclosing agro-industrialism, the evolution of a more algorithmically complex knowledge economy erodes such space-tethered cleavages (but not without friction or reversals).

\section{Progressive uncoupling from geophysical location: the leveling of racial-ethnic hierarchies by epistemic-geopolitical networks and the nativist backlash}

Coevolving with less rigid national borders, cybernetic parallelism has reduced racial-ethnic barriers in the post-colonial era. Signals from diverse global activists have challenged the boundaries of empires. Key activists include anticolonial intellectuals and movements, as well newly independent governments in Asia, Africa, and Latin America. Their signals convey that use of police power to "racially" partition space, whether in ethnic ghettos or abroad, comes with a price. Such use of police power hinders the post-colonial world's vigorous pursuit of military, economic, and diplomatic alliances. These strategic global partnerships have created more inclusive boundary alignments-indeed, a phase-transition edge preserving social order-in the chaos of WWII and the Cold War (see FitzGerald and CookMartin 2014). Significantly, WWII's Allies defeated apartheid-promoting Axis empires (with ethnic ghettos) and then integrated them into more inclusive postwar alliances. These alliances eventually dismembered racial-ethnic spatial partitioning under formal apartheid. The Allied victory also discredited, but did not eliminate, eugenics ideology legitimating racial hierarchy (see Black 2012).

\footnotetext{
17 Kurokawa and Ihara (2017) use a stochastic evolutionary model showing that groupwise cooperation is most likely if individual benefits do not diminish with increasing group size.

18 Mayfield (2013) observes that simple input can create complexity, especially if each output is input to another round of processing or computation. Iterations, then, are central to complexity.
} 
Similarly, racial-ethnic hierarchies have been partially leveled by securityenhancing Cold War alliances. Horizontal realignment of the US defense perimeter required cooperation from decolonized nations in Asia, Latin America, and Africa. Conscious of this, US presidents from Truman through Johnson lobbied for civil rights and for eliminating ethnically selective immigration quotas (Dudziak 2011; Tichenor 2002). Remarkably, by 2008, diplomatic alliances and trade expansion had contributed to eliminating ethnic-group exclusion or restriction-for Chinese, Japanese, Roma, Jews, blacks, or Middle Easterners-in the immigration laws for all 22 countries in the Americas (see FitzGerald and Cook-Martin 2014: 39-42). Again, this erosion of geo-ethnic checkpoints has arisen at the edge of chaos generated by unsustainable, violent boundary disputes: two world wars, unrelenting insurgencies, the 1960 Sharpeville massacre, the Civil Rights movement's "Bloody Sunday" in 1965, etc. However, it is also true that checkpoint-eliminating alternatives emerged from horizontally exerted soft power.

Significantly, soft-power challenges to geo-ethnic checkpoints have been conceived by an emergent, knowledge-wielding expert class. A very diverse group of well-educated intellectuals led anticolonial and anti-segregation movements that have eroded geo-ethnic boundaries. Prominent leaders with university degrees are too numerous to list here: Mahatma Ghandi (University of London), José Martí (Central University of Madrid), Kwame Nkrumah (University of London), Jomo Kenyatta (London School of Economics), Amílcar Cabral (University of Lisbon), Nelson Mandela (University of the Witwatersrand), Martin Luther King (Ph.D. from Boston University), Mao Zedong (First Provincial Normal School in Changsha), etc. These leaders not only absorbed globally dispersed knowledge, but recombined it in innovative, region-specific ways. They constitute, from an evolutionary informatics perspective, diverse and independent agents learning from their mutual exchange of signals. This emergent community is a complex adaptive system increasingly reliant on global information flows (see top of Fig. 1).

As society's boundaries have been shifting from geophysical sites to worldwide connectivity in clouds via 5G and IoT, the boundary-challenging expert class has increasingly networked in global epistemic communities. ${ }^{19}$ These specialist networks - guided by evidentiary norms of validity and reliability and a common purpose-exchange information on complex problems requiring application of scientific or technical expertise (Haas 1992). For example, a UN scholar and activist from India, E. S. Reddy (M.A. from New York University), played a key role in promoting international sanctions against South African apartheid (Korey 1998; for college degree, see Yale University Library 2019) ${ }^{20}$ The American Committee on

\footnotetext{
19 In networks, the connections or paths for signals - the logical or signal topology — can be very different than underlying physical connections that comprise the physical topology (Tomsho 2016). Moreover, according to Mayfield (2013: 44), "a remarkable feature of algorithms is that their logical structure transcends the physical system they are encoded in." Because of this transcendence, the information revolution creates an increasingly location-free logical topology. One consequence is the erosion of geophysical boundaries blocking signals within and between epistemic communities (see Keck and Sikkink 1998).

20 E. S. Ready served as chief of the UN Special Committee against Apartheid. In this capacity, he organized an Ad Hoc Working Group of Experts in 1967.
} 
Africa (ACOA), the brainchild of George Houser (educated at the Union Theological Seminary), was one of many NGOs developing alternative ideas for sanctions, divestment, and loan denials to defeat South African apartheid (Korey 1998). In still another instance of successful soft power, the global professional intelligentsia guided all 22 countries in the Americas into signing ICERD, the International Convention on the Elimination of All Forms of Racial Discrimination (Burke 2010; FitzGerald and Cook-Martin 2014). Ultimately, increasing leverage for the professional intelligentsia's epistemic communities arises from a growing reliance on technical expertise, on information combined in novel ways, and on horizontal networking that overcomes the inertia of large, vertically integrated institutions (Haas 1992; Powell 1990). As global complexity grows, a premium derives from open innovation processes (Witt 2016). Such processes are greatly advanced when informationpossessing perfectly partible value - is offered as a public good.

It is evident that borderless epistemic networks can challenge the space-enclosing logic of racial-ethnic barriers. Yet, brewing outside these networks is a turfdefending, nativist backlash (Kobrin 2017). In terms of evolutionary informatics, the backlash may represent the landlocked heartland walling off boundary-crossing signals from the globe's most networked domains. Multinational values and lifestyles in worldly cities are resisted by interior regions more strictly adhering to traditional boundaries and local customs.

Significantly, resurgent nativism may be a response to entropic debt associated with globalization's impact on less networked and less adaptive structures. For example, switching costs arise from automation and unequally distributed "gains from international openness" (Kobrin 2017: 162). In a study of 25 advanced economies between 2005 and 2014, the findings reveal real market incomes for two-thirds of households either stagnated or fell (McKinsey Global Institute 2016). ${ }^{21}$ Boxed in by this economic horizon, less networked (non-cosmopolitan) stakeholders resent losing sovereignty over localities or conceding cultural and political space-e.g., the Brexit rebellion against London's EU connection. When the stakeholder's identity is invested in a familiar place ${ }^{22}$ rather than in exploring new venues, sharing one's space with foreign people and cultures generates a zero-sum dynamic (see Kobrin 2017). Consistent with findings concerning fixed-site rivalrous benefits, a re-emergent nativist territoriality may reflect economic and spatial displacement-real and perceived-for the heartland population. The consequent zero-sum dynamic may be reinvigorating geo-ethnic cleavages. Complex systems can devolve toward greater simplicity, as evidenced by Nazi Germany (see Weidlich 2000). Complex systems may entirely collapse from mounting entropy debt as did the Roman Empire, which suffered diminishing returns from its overtaxed dominions (see Tainter 1988).

\footnotetext{
${ }^{21}$ Results are based on a population-weighted average of pre-tax and pre-transfer incomes for Australia, Austria, Belgium, Canada, Czech Republic, Denmark, Finland, France, Germany, Greece, Hungary, Iceland, Italy, Ireland, Luxembourg, Netherlands, New Zealand, Norway, Portugal, Slovenia, Spain, Sweden, Switzerland, United Kingdom, and the United States.

22 A familiar context demands fewer cognitive resources to be successfully navigated, in part due to repetition priming (Meagher 2014). This context becomes a "primary territory" when "central to oneself" (Altman 1975).
} 


\section{Conclusion}

It is theorized that the erosion — and greater permeability — of geo-ethnic boundaries is ultimately enabled by the progressive uncoupling of more highly evolved complex adaptive systems from geophysical location. That is, the boundaries marking racial and ethnic cleavages are rooted in socio-geographic processes such as metropoledirected resource extraction from tropical landscapes. These processes required nonmarket spatial segregation of populations tagged with hinterland lineage. However, entropic debts arise from merely walling in fixed-site benefits and ignoring ecological webs of interconnection. A key benchmark has been the post-WWII collapse of colonial empires and some of their least ecologically sustainable landscape-altering projects.

From an evolutionary informatics perspective, society's progressive uncoupling from geophysical location does not entail greater independence from the surrounding ecological system. Quite the contrary, this uncoupling requires more innovative, information-driven adaptations. Innovations entail crossing boundaries to connect resources grounded in separated networks (Granovetter 2005; Schumpeter 1983). By crossing boundaries, the digital age promotes cybernetic parallelism: increasingly interactive, independent power centers enabling multiethnic globalism. However, in light of the current nativist resurgence, unraveling geo-ethnic boundaries may be convulsing toward more "racially" divisive, authoritarian governance. The trajectory of the unfolding chaos is unclear, because, consistent with the most fundamental postulate of evolutionary informatics, not all signal-boundary systems successfully adapt.

Acknowledgements Thanks are given to Qing Lai, Rae Choi, and Yvonne Girard for critical comments. Lenori Bonfante was an admirable research assistant.

\section{Compliance with ethical standards}

Conflict of interest The author states that there is no conflict of interest.

Ethical approval This article does not contain any studies with human participants or animals performed by the author.

Open Access This article is distributed under the terms of the Creative Commons Attribution 4.0 International License (http://creativecommons.org/licenses/by/4.0/), which permits unrestricted use, distribution, and reproduction in any medium, provided you give appropriate credit to the original author(s) and the source, provide a link to the Creative Commons license, and indicate if changes were made.

\section{References}

Adami C (2002) What is complexity. BioEssays 24:1085-1094

Adas M (1989) Machines as the measure of men: science, technology, and ideologies of western dominance. Cornell University Press, New York

Alexander M (2012) The new Jim Crow: mass incarceration in the age of colorblindness. The New Press, New York 
Altman I (1975) The environment and social behavior: privacy, personal space, territory, and crowding. Brooks/Cole Publishing Company, Monterey

Arthur WB (1994) Increasing returns and path dependence in the economy. University of Michigan Press, Ann Arbor

Ashby WR (1956) An introduction to cybernetics. Chapman \& Hall, London

Azzi G (1956 [1925]) Agricultural ecology. Constable, London

Becker GS (1971 [1957]) The economics of discrimination. University of Chicago Press, Chicago

Beckert S (2015) Empire of cotton: a global history. Knopf, New York

Benbya H, McKelvey B (2006) Toward a complexity theory of information systems development. Inf Technolog People 19(1):12-34

Berg E (2007) Examining power-sharing in persistent conflicts: de facto pseudo-statehood versus de jure quasi-federalism. Glob Soc 21(2):199-217

Black E (2012) War against the weak: eugenics and America's campaign to create a master race. Dialog Press, Washington

Bonilla-Silva E (2018) Racism without racists: color-blind racism and the persistence of racial inequality in America, 5th edn. Rowman and Littlefield, New York

Burke R (2010) Decolonization and the evolution of international human rights. University of Pennsylvania Press, Philadelphia

Camp SMH (2004) Closer to freedom: enslaved women and everyday resistance in the plantation South. University of North Carolina Press, Chapel Hill

Carlson RP, Beck AE, Phalak P, Fields MW, Gedeon T, Hanley L, Harcombe WR, Henson MA, Heys JJ (2018) Competitive resource allocation to metabolic pathways contributes to overflow metabolisms and emergent properties in cross-feeding microbial consortia. Biochem Soc Trans 46(2):269-284

Carpenter FL, MacMillen RE (1976) Threshold model of feeding territoriality and test with a Hawaiian honeycreeper. Science 194(4265):639-642

Cashdan E (1983) Territoriality among human foragers: ecological models and an application to four Bushman groups. Curr Anthropol 4(1):47-66

Chadefaux T, Helbing D (2010) How wealth accumulation can promote cooperation. PLoS One 5(10):e13471

Corning PA, Kline SJ (1998) Thermodynamics, information and life revisited, part ii: "thermoeconomics" and "control information". Syst Res Behav Sci 15(6):453-482

Corning PA, Szathmáry E (2015) "Synergistic selection:" a Darwinian frame for the evolution of complexity. J Theor Biol 371(21):45-58

Darwin C (1859) On the origin of species. John Murray, London

Dudziak M (2011) Cold war civil rights: race and the image of American democracy. Princeton University Press, Princeton

Dumont R (1966) False start in Africa. Translated by Ott PN. Praeger, New York

Dyke C (1988) Cities as dissipative structures. In: Weber BH, Depew DJ, Smith JD (eds) Entropy, information, and evolution: new perspectives on physical and biological evolution. MIT Press, Cambridge, pp 355-367

Edwards AWF (2003) Human genetic diversity: Lewontin's fallacy. BioEssays 25(8):798-801

Engerman SL, Sokoloff KL (1997) Factor endowments, institutions, and differential paths of growth among new world economies. In: Haber S (ed) How Latin America fell behind: essays on the economic histories of Brazil and Mexico, 1800-1914. Stanford University Press, Stanford, pp 260-304

Faulkner OT, Mackie JR (1933) West African agriculture. Cambridge University Press, Cambridge

Findlay R, O'Rourke K (2007) Power and plenty: trade, war, and the world economy in the second millennium. Princeton University Press, Princeton

Fisk ST (2011) Envy up, scorn down: how status divides us. Russell Sage Foundation, New York

FitzGerald DS, Cook-Martin D (2014) Culling the masses: the democratic origins of racist immigration policy in the Americas. Harvard University Press, Cambridge

Foster J (2011) Evolutionary macroeconomics: a research agenda. J Evol Econ 21(1):5-28

Fredrickson GM (1981) White supremacy: a comparative study of American and South African history. Oxford University Press, Oxford

Granovetter M (2005) The impact of social structure on economic outcomes. J Econ Perspect 19(1):33-50

Haas P (1992) Introduction: epistemic communities and international policy coordination. Int Organ 46(1): $1-35$

Haberl H, Fischer-Kowalski M, Krausmann F, Martinez-Alier J, Winiwarter V (2011) A socio-metabolic transition towards sustainability? Challenges for another great transformation. Sustain Dev 19:1-14 
Havinden M, Meredith D (1993) Colonialism and development: Britain and its tropical colonies, 1850-1960. Routledge, London

Headrick DR (1981) The tools of empire: technology and European imperialism in the nineteenth century. Oxford University Press, New York

Hinton E (2016) From the war on poverty to the war on crime: the making of mass incarceration in America. Harvard University Press, Cambridge

Holland JH (2006) Studying complex adaptive systems. J Syst Sci Complex 19:1-8

Holland JH (2012) Signals and boundaries: building blocks for complex adaptive systems. MIT Press, Cambridge

Jablonka E, Lamb MJ (2006) The evolution of information in the major transitions. J Theor Biol 239(2):236-246

Johnson DP, Toft MD (2013) Grounds for war: the evolution of territorial conflict. Int Secur 38(3):7-38

Jones HG (1936) The earth goddess: a study of native farming on the West African coast. Longmans, London

Jones-Correa M (2000-2001) The origins and diffusion of racial restrictive covenants. Polit Sci Q 115(4):541-568

Kauffman SA (1993) The origins of order. Oxford University Press, New York

Keck ME, Sikkink K (1998) Activists beyond borders: advocacy networks in international politics. Cornell University, Ithaca

Kim E, Ashlock D (2017) On the design of game-playing agents. Morgan and Claypool Publishers, Williston

Kobrin SJ (2017) Bricks and mortar in a borderless world: globalization, the backlash, and the multinational enterprise. Glob Strategy J 7(2):159-171

Korey W (1998) NGO's and the Universal Declaration of Human Rights: "a curious grapevine". Palgrave, New York

Kurokawa S, Ihara Y (2017) Evolution of group-wise cooperation: is direct reciprocity insufficient? J Theor Biol 415(21):20-31

Lathrop JI (1997) Computing and evolving variants of computational depth. Dissertation, Iowa State University

Lewontin RC (1972) The apportionment of human diversity. Evol Biol 6:381-398

Marks J (2010) Ten facts about human variation. In: Muehlenbein MP (ed) Human evolutionary biology. Cambridge University Press, Cambridge, pp 265-276

Massey DS (2004) Segregation and stratification: a biosocial perspective. Du Bois Rev 1(1):7-25

Massey DS, Denton NA (1988) The dimensions of residential segregation. Soc Forces 67(2):281-315

Massey DS, Denton NA (1993) American apartheid: segregation and the making of the underclass. Harvard University Press, Cambridge

Massey DS, Tannen J (2015) A research note on trends in black hypersegregation. Demog 52(3):1025-1034

Massey DS, Wagner B (2018) Segregation, stigma, and stratification: a biosocial model. In: Major B, Dovidio JF, Link BG (eds) The Oxford handbook of stigma, discrimination, and health. Oxford University Press, New York, pp 147-162

Mayfield JE (2013) The engine of complexity: evolution as computation. Columbia University Press, New York

Maynard Smith J, Szathmáry E (1995) The major transitions in evolution. Oxford University Press, Oxford

Maynard Smith J, Szathmáry E (1999) The origins of life: from the birth of life to the origin of language. Oxford University Press, Oxford

McKinsey Global Institute (2016) Poorer than their parents? Flat or falling incomes in advanced economies. July. McKinsey Global Institute, San Francisco, CA. https://www.mckinsey.com/ /media/ McKinsey/Featured\%20Insights/Employment\%20and\%20Growth/Poorer\%20than\%20their\%20par ents\%20A\%20new\%20perspective\%20on\%20income\%20inequality/MGI-Poorer-than-their-parentsFlat-or-falling-incomes-in-advanced-economies-Full-report.ashx

Meagher BR (2014) The emergence of home advantage from differential perceptual activity. Dissertation, University of Connecticut

Mitchell C, Hobcraft J, McLanahan SS, Siegel SR, Berg A, Brooks-Gunn J, Garfinkel I, Notterman D (2014) Social disadvantage, genetic sensitivity, and children's telomere length. Proc Natl Acad Sci USA 111(16):5944-5949

Montgomery JD (1991) Social networks and labor-market outcomes: toward an economic analysis. Am Econ Rev 81(5):1408-1418

Moore JW (2000) Environmental crises and the metabolic rift in world-historical perspective. Organ Environ 13(2):123-157 
Oliver ML, Shapiro TM (2006) Black wealth/white wealth: a new perspective on racial inequality, 2nd edn. Routledge, New York

Pacheco AR, Moel M, Segrè D (2019) Costless metabolic secretions as drivers of interspecies interactions in microbial ecosystems. Nat Commun 10:103

Philpott TL (1991) The slum and the ghetto: immigrants, blacks, and reformers in Chicago, 1880-1930. Wadsworth, Belmont

Pincus S (2012) Rethinking mercantilism: political economy, the British Empire, and the Atlantic world in the seventeenth and eighteenth centuries. William Mary Q 69(1):3-34

Powell WW (1990) Neither market nor hierarchy: network forms of organization. Res Organ Behav 12:295-336

Rizzo M (2006) What was left of the groundnut scheme? Development disaster and labour market in Southern Tanganyika 1946-1952. J Agrar Chang 6(2):205-238

Roberts D (2011) Fatal invention: how science, politics, and big business re-create race in the twenty-first century. The New Press, New York

Roithmayr D (2014) Reproducing racism: how everyday choices lock in white advantage. New York University Press, New York

Ross C (2017) Ecology and power in the age of empire: Europe and the transformation of the tropical world. Oxford University Press, New York

Sack RD (1983) Human territoriality: a theory. Ann Assoc Am Geogr 73(1):55-74

Schulz AJ, Mentz G, Lachance L, Johnson J, Gaines C, Israel BA (2012) Associations between socioeconomic status and allostatic load: effects of neighborhood poverty and tests of mediating pathways. Am J Public Health 102(9):1706-1714

Schumpeter JA (1983 [1934]) The theory of economic development: an inquiry into profits, capital, credits, interest, and the business cycle. Translated from the German by Opie R. With a new introduction by Elliott JE. Routledge, New York

Stein GJ (1999) Rethinking world-systems: diasporas, colonies, and interaction in Uruk Mesopotamia. University of Arizona Press, Tucson

Street P (2002) The vicious circle: race, prison, jobs, and community in Chicago, Illinois and the nation. Department of Research and Planning, Chicago Urban League

Szathmáry E (2015) Toward major evolutionary transitions theory 2.0. Proc Natl Acad Sci USA 112(33):10104-10111

Tainter JA (1988) The collapse of complex societies. Cambridge University Press, Cambridge

Tassier T, Menczer F (2008) Social network structure, segregation, and equality in a labor market with referral hiring. J Econ Behav Organ 66(3-4):514-528

Tichenor DJ (2002) Dividing lines: the politics of immigration control in America. Princeton University Press, Princeton

Toft MD (2002) Indivisible territory, geographic concentration, and ethnic war. Sec Stud 12(2):82-119

Tomsho G (2016) Guide to networking essentials, 7th edn. Cengage Learning, Boston

Tucker R (2000) Insatiable appetite: the United States and the ecological degradation of the tropical world. University of California Press, Berkeley

Uggen C, Manza J, Thompson M (2006) Citizenship, democracy, and the civic reintegration of criminal offenders. Ann Am Acad Political Soc Sci 605(May):281-310

University of Edinburgh (2016) "What is informatics?" https://www.ed.ac.uk/files/atoms/files//what20is20 informatics.pdf. Accessed 19 July

von Schilling C, Straussfogel D (2009) Entropy debt: a link to sustainability? In: Proceedings of the 53rd annual meeting of the international society for the systems sciences. University of Queensland, Brisbane, Australia, July 12-17. http://journals.isss.org/index.php/proceedings53rd/article/view/1302

Weidlich W (2000) Sociodynamics: a systematic approach to mathematical modelling in the social sciences. Taylor \& Francis Group, London

Western B (2006) Punishment and inequality in America. Russell Sage Foundation, New York

Witt U (2016) What kind of innovations do we need to secure our future? J Open Innov technol Mark Complex 2(17): $1-14$

Wolfram S (2002) A new kind of science. Wolfram Media, Champaign

World Bank (2003) Zambia - copperbelt environment project. World Bank, Washington, DC. http://docum ents.worldbank.org/curated/en/133781468781554158/Zambia-Copperbelt-Environment-Project

Yale University Library (2019) E. S. Reddy papers. MS 1499. http://drs.library.yale.edu/HLTransformer/ HLTransServlet?stylename=yul.ead2002.xhtml.xsl\&pid=mssa:ms. $1499 \&$ clear-stylesheet-cache=yes 
Publisher's Note Springer Nature remains neutral with regard to jurisdictional claims in published maps and institutional affiliations. 